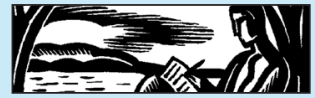

\title{
Exploring the Nature of the Dialogical Self: The Young Widow Memoir
}

\author{
Katrin Den Elzen
}

Curtin University, Perth, Australia

\section{ABSTRACT}

This paper intends to contribute to the ongoing debate on identity construction by offering a textual analysis of two memoirs that depict the experience of young widowhood: Unremarried Widow by Artis Henderson (2014) and When it Rains by Maggie MacKellar (2010). I refer to the texts as young widow memoirs and identify them as a sub-genre of the grief memoir. Drawing on Paul Eakin's concept of narrative identity and Hubert Hermans' dialogical self theory, the analysis investigates how the memoirists use narrative to negotiate and represent the multiple subject positions and conflicting voices that arise out of the experience of young widowhood, and how they position selves which existed prior to their loss in relation to their post-loss selves. The memoirs under review are shown to rebuild a relatively stable sense of self out of the multiple voices of loss.

Keywords: grief, memoir, identity, young widowhood

\section{INTRODUCTION}

Losing one's spouse at a young age is one of the most difficult experiences we may face in life. It typically contests our sense of self and evokes new subject positions that were not present prior to the experience of loss. This paper intends to contribute to the ongoing debate on identity construction by offering a textual analysis of two memoirs that depict the experience of young widowhood: Unremarried Widow by Artis Henderson (2014) and When it Rains by Maggie MacKellar (2010). ${ }^{1}$ I refer to 
the texts as young widow memoirs and categorise them as a sub-genre of the grief memoir. My reading of these memoirs is informed by the concept of the dialogical self, which views the self as consisting of multiple, relatively autonomous voices or 'I-positions', each with their unique perspective, that engage in dialogue with one another akin to interpersonal dialogue. ${ }^{2}$ The analysis will investigate how the memoirists use narrative to negotiate and represent the multiple subject positions and conflicting voices that arise out of their lived experience of widowhood, and how they position and juxtapose selves which existed prior to their loss with their post-loss selves.

This paper draws on a concept of the self that integrates the notion of the unified self with the multi-voiced self, which views unity in the self as narrative coherence that is constructed in autobiographical writing out of the ongoing, complex dialogical relations between multiple, at times adversarial, subject positions. ${ }^{3}$ It will show that the memoirs under review rebuild a relatively stable sense of self out of the voices of loss.

\section{ABOUT THE AUTHORS}

MacKellar and Henderson have written debut memoirs. The authors were in their late twenties when their husbands died and in their early to mid-thirties when they wrote and published their memoirs. Prior to writing her memoir, MacKellar had published two books on the history of settlement in Australia and Canada. There is a connection between her writing about female settlers on the frontier and her own move from Sydney to the country following the loss of her husband. She has written a sequel to her first memoir entitled How to get there (2014), ${ }^{4}$ which depicts a new relationship a decade after her loss. MacKellar is now a full-time writer; she runs writers' retreats in Australia and is a speaker at writers' festivals. Henderson similarly became a professional writer after being widowed. She attended Columbia University following her husband's death and earned a master's in journalism. She then became an award-winning journalist and essayist. ${ }^{5}$ Currently she runs national and international memoir writing workshops and offers private manuscript consultations.

The debut memoir is characteristic of the young widow memoir as a contemporary sub-genre of life writing. I am referring to this sub-genre as young widow memoir to denote that the experience of widowhood at a younger age is different to that of widowhood at an older age. Young widowhood is unexpected and goes against the life cycle. Unlike older widowhood, it is a rare experience that puts the women at odds with their 
contemporaries. ${ }^{6}$ The themes addressed in the memoirs under review are typical of this sub-genre: representing the loss of identity following the death of their spouse, narratively exploring the alien identity of widow and rebuilding a new sense of self by textually negotiating the conflicting voices that have arisen out of the experience of young widowhood by interspersing vivid description in the style of creative non-fiction with inner monologue and reflection.

Whilst the themes that are textually represented are characteristic of the sub-genre, each of these texts mediates a specific kind of loss, such as dealing with suicide and military culture; in the field in general, such texts also depict widowhood through cancer, violent loss and multiple losses. As such, each memoir mediates a particular kind of experience that is representative of premature spousal loss but is at the same time unique to the author.

\section{THE YOUNG WIDOW MEMOIR}

Memoirs concerned with young widowhood have not specifically been the subject of academic analysis before. I am suggesting that they are particularly interesting in the way that they raise questions about narrative construction of selfhood that have been debated in autobiography studies. When it Rains by Maggie MacKellar (2010) and Unremarried Widow by Artis Henderson (2014) are two texts that allow us to see questions about autobiographical self-construction in sharp relief. MacKellar's memoir depicts her husband's unexpected and sudden descent into mental illness after ten years of marriage, his suicide whilst she was pregnant with their second child and her own recovery from her bereavement which sees her moving from the city to the country with her young children. Unremarried Widow depicts Henderson's experiences as military spouse, her low status as a girlfriend within military culture, her wedding just four months before her husband's death, and her journey of recovery from grief.

By definition, young widow memoirs are concerned with loss. The death of one's partner is a difficult, distressing and challenging experience. The literature on young widowhood reports that for young widows the death of their husband is an unexpected event that goes against the normal life cycle and results in a loss of identity. ${ }^{7}$ For the purpose of this paper and in the context of Western memoirists I define young widows as being women up until the age of forty-five. The twenties until the midforties are located in the prime of one's life cycle and are considered in Western culture to be young to face the premature death of one's spouse given the overall life expectancy of over eighty years. 
Research into the impact of age on a widow's grief shows that age does play a major role in bereavement. ${ }^{8}$ The implications are that for young widows, widowhood is not merely a state of mourning, but rather a process of adaptation which is largely a process of identity reconstruction, as premature loss results in identity discontinuity. ${ }^{9}$ It is this well-documented loss of identity occasioned by the advent of young widowhood and the subsequent need to rebuild the self which makes the young widow memoir of particular interest to scholarly examination of narrative identity construction.

Sidonie Smith and Julie Watson highlight that autobiographical writing generally draws from multiple, incongruent and 'discontinuous experiences' and gives voice to the multiple identities that are constructed from those experiences. ${ }^{10}$ Life writing allows young widows, in particular, to mediate the experience of spousal loss, and specifically to give voice to their pre- and post-loss selves that are positioned in a conflictual relationship in the text. The autobiographical narrator 'comes to consciousness' of who they are; they construct identity through the process of textually negotiating multiple voices. ${ }^{11}$ I conceptualise autobiographical writing, then, as the performative act of narrative identity construction, through a medium that is well suited to the act of negotiating dialogical selves, specifically, mediating the multiple subject positions that arise out of the experience of loss.

\section{DEBATES ABOUT SUBJECTIVITY AND NARRATIVE IDENTITY CONSTRUCTION}

Subjectivity and the nature of the self is a much debated and contested topic in critical scholarship. One of the main debates has centred on the question of a core self. The notion of selfhood that is dominant in modernity conceptualises the self as an essential entity that exists at the core of individuals, a true and real self that is immutable and that can be discovered. ${ }^{12}$ This essentialist view of the self was attacked by post-structuralist thinkers who contested the existence of an innate core self and conceptualised the self as continually constructed through language and as being subjected to social, cultural and ideological forces. ${ }^{13}$ However, the rejection by post-structuralism of the self as an innate entity has led to an uncompromising dismissal of the possibility that there might be "anything innate in the development of the self' or a "self" at all'.14

Out of these two diametrically opposed positions another model has been conceptualised within autobiography and narrative psychology theory, which integrates aspects of both concepts: the notion of a relatively 
stable-or unified-sense of self, and the post-structural theorising of the self as being continually constructed out of multiple voices. Paul Eakin has stated that 'announcements of the death of the unified self are premature..$^{15} \mathrm{He}$ explains that 'such either/or polarities—identity as either fixed and stable or fragmented and fluid- strike me as inadequate to address the complexity of identity experience; they fail to capture how identity can change over time and yet in some way remain recognisably the same. ${ }^{16}$ Like Eakin, psychologist Hubert Hermans views the notions of unity and multiplicity as compatible rather than mutually exclusive. Hermans developed the dialogical self theory, whereby the dialogical self is conceptualised as a 'dynamic multiplicity of I-positions'. Akin to interpersonal dialogue, these I-positions are involved in the dynamic process of dialogue, of negotiation and exchange. ${ }^{17}$ These multiple selves are localised in a particular time, place and context and are influenced by cultural and social forces as well as belief systems and ideologies which shape the voices that are available to the narrator. The dialogical self is conceived as being narratively structured. ${ }^{18}$ The constructive activity of emplotment makes juxtaposing of voices and events possible, whereby the notion of space becomes paramount over the original time sequence. Hermans refers to this process of juxtaposing as positioning and repositioning. He frames unity in the self as the result of a developmental process and not as a core fixed self. ${ }^{19}$

Narrative psychologist Dan McAdams also views identity as being forged in narrative. He highlights the power of narrative to construct coherence and a relatively stable sense of self. In an article entitled 'The Case for Unity in the (Post) Modern Self' he states that self-narrative offers 'an integrative framework' for the incorporation of multiple selves, including possible selves, ideal selves, undesired selves and selves with others. ${ }^{20}$ Narrative coherence is seen to depend on the integration of the 'shifting and dynamic dialogue among the voices'. ${ }^{21}$ Eakin has summed up the conundrum that arises out of the apparent incompatibility of unity and multiplicity by positioning it in relation to autobiographical narrative, which he sees as invoking 'a psychological binary-an I-narrator in the present in dialogue with an I-character in the past-might be designed precisely to solve the conundrum of continuous identity: how we manage-if we do-to change over time and yet remain in some deep sense the same. ${ }^{22}$

Consistent with the notion of a dialogical self this paper conceptualises the self as dialogical, historical, localised, gendered, embodied, socialised and cultural. ${ }^{23}$ It argues for an integrated concept of unity of the self and the presence of multiple voices in autobiographical narrative, viewing unity in the self as narrative coherence that is textually constructed out of the ongoing, complex dialogical relations between 
multiple, at times adversarial, subject positions. ${ }^{24}$ The process of constructing such a relatively stable sense of self out of the multiplicity of voices is not to be seen as a neat and tidy affair without remaining struggles. Narrative identity construction is conceptualised as a complex dialogical, multilayered and ongoing developmental process. I would like to emphasise here that I am not suggesting that autobiographical writing inherently brings about coherence and a sense of unity, only that it can do so.

\section{THE VOICE OF GRIEF IN YOUNG WIDOW NARRATIVES}

The intensity of the voice of loss is evident in Maggie MacKellar's memoir When it Rains. The voice of grief is metaphorically conveyed as embodied, personified and forceful:

My sorrow has arms and legs, fingers and toes. It has a mind and a heart: it bleeds and dies. It breathes and sobs, howls and laughs.... I walk around in it. It is anger and rage.... It is vulnerable and needs to be held. It is impenetrable, an armour that cannot be pierced. ${ }^{25}$

Similarly, Artis Henderson also employs metaphor to convey her felt pain. The voice of grief symbolically draws on the physicality of broken limbs to denote her vulnerability: 'I had to steady myself the way a person steadies a broken arm, to keep from knocking into the hurt. And still, despite my best efforts, I often bumped against the pain'. ${ }^{26}$ Like MacKellar, Henderson's voice of grief symbolically draws on the image of bleeding to signify the extent of her felt sorrow: 'the sadness that flowed like blood beneath my skin threatened to spill out'. ${ }^{27}$ These passages highlight the embodiment of our experience in general, and the bodily connection in grief in particular. Smith and Watson posit that autobiographical writing links subjectivity, memory and the material body. They emphasise that autobiographical narrators are embodied subjects and that memory itself is embodied, thereby framing the body as the site of autobiographical knowledge. In their view the embodied nature of autobiographical writing can easily be forgotten, stating that it 'is easy to think' that autobiographical texts are separate from the material body. ${ }^{28}$ The physical metaphors that denote grief employed in the texts serve as a reminder of the embodiment of autobiographical knowledge.

Beyond the felt intensity of anguish, MacKellar fears that her grief has the power to erase her selfhood by defining her exclusively through that grief. ${ }^{29}$ Contemporary bereavement theory posits that the premature loss 
of a loved one generally leads to a shattering of the self..$^{30}$ This is evident in MacKellar's subject position of a widow who no longer recognises herself: 'I feel so disconnected from who I used to be that I wonder whether I'll ever be comfortable in myself again. This body is as foreign to me as this life I'm living without him. ${ }^{31}$

The voice of grief recognises that she is lost and sees the act of writing as the key to finding the path to a subject position of recovery. Again, she draws on an anatomical metaphor to denote the process of deliberately taking back control: 'I pin my tragedy onto the paper and with the precision of an anatomist take a scalpel to separate memory from bone. Perhaps if I can peel the layers of skin from its torso, it will stop having the power of a dark shape in the night.' ${ }^{32}$

\section{CONFLICTING SELVES ARISING OUT OF LOSS}

In the two memoirs under review incompatible, conflictual voices are represented in the texts. In particular, the authors' dominant pre- and post- loss selves are placed in an adversarial relationship. For the purpose of this paper, I will focus my lens on these dominant confrontational relationships in the text, though it is important to note that multiple other voices are also narrated in the memoirs and placed in dialogical interaction with the adversarial selves.

Henderson's narrative gives voice to two dominant, adversarial subject positions. There is the pivotal voice of happiness through love, narrated in inner monologue:

How could I tell him that Miles was what I had been looking for my entire life? That the great lonely space inside me, deep and wide as a canyon, shrank to nothing when Miles stepped into the room? That even in that shitty job in that god-awful town I still considered myself a lucky, lucky girl. ${ }^{33}$

This is juxtaposed with the voice that dreams of being a writer: 'As long as I could remember, I wanted to be a writer. ${ }^{34}$ This self is further narratively positioned as being in conflict with the voice that perceives this dream to be out of reach for 'people like me'. She refers here to 'poor' people who do not have the right middle-class background: 'people from where I'm from, we don't live that life. We don't become writers. We don't move overseas, ${ }^{35}$

The happiness-through-love voice is represented as giving up her own dreams in order to play a supporting role in her partner's life and military career, though not without doubt: 'how would I navigate this life for the long haul? Where would my own dreams and ambitions fit in?"36 This 
voice is also placed in opposition to the independent self that was politically active on campus and known for having strong opinions on gender politics. ${ }^{37}$

The narrative device of juxtaposing positions shows the spatial nature of the dialogical self, whereby space is given priority over time, over chronological sequencing of the narrative. That means the original time sequence is changed in the performance of making new configurations. ${ }^{38}$ The voices of dreaming of being a writer and of fulfilment through love are positioned as being mutually exclusive due to the nature of the military lifestyle that is characterised by frequent moving. When Miles is stationed in North Carolina after graduating from flight school Henderson decides to leave sunny Florida in order to move in with him. Whilst the car slips on icy roads on the way to the base Henderson is shown to wonder how she is going to 'weather Army life'. She draws on the metaphor and symbolism of a cold front in order to portray her unease about the army:

My knuckles were rubbed raw in the chill and damp as we toted our combined life ... jugs of olive oil turned cloudy in the cold... The rooms filled with a heavy animal smell when we ran the gas heater. ${ }^{39}$

She represents her opposing emotions, the unease about her new life as military girlfriend and her deep love for Miles: 'by all accounts our place was shoddy-but I loved it. I loved having a house of our own. ${ }^{40}$

The self that yearns to realise her dreams is riddled with uncertainty even on the eve of receiving Miles' marriage proposal: she looked at herself in the mirror for a long time in an act of trying to determine if she resembled the woman she had once been. This voice is portrayed as troubled about being unable to recognise herself in the mirror and is even shown to have contemplated leaving Miles. ${ }^{41}$ This shows the extent of the conflict between the voice that is deeply in love and the self that has to give up her old life, her independence as well as her own dreams in order to live with Miles.

Miles is a significant other to Henderson. This is evident through Henderson's representation of Miles, who is shown to offer to fulfil her yearning for love, which causes her to place such significance and value on him that this represses and silences the self that wishes to achieve her dreams, albeit with uncertainty. The suppression of the voice of self-fulfilment highlights that some subject positons dominate other positions, thereby overpowering them. ${ }^{42}$

The notion of 'the other' is an intrinsic component of the dialogical self theory, which conceptualises the other not as simply external to the self, but as 'simultaneously part of the self and even constitutive of it'. ${ }^{43}$ 
The concept of the self is extended, whereby subject positions refer both to internal voices and to significant others that have become internalised by the self, such as 'my husband' or 'my mother'. Intersubjectivity is not seen as being added onto a pre-existing core self, but as intrinsic to its dialogical nature, whereby internal and external subject positions are involved in the dynamic process of dialogue, negotiation and exchange. This internalisation process has been termed 'the-other-in-the-self', ${ }^{4}$

Another influential other to Henderson is her mother. In a tragic repetition of fate Henderson's father died in a plane crash when she was five years of age, as did her husband later on. Her relationship with her mother is represented as complex and strained, because she had always felt hurt that her mother erased her father from her life and angry at her mother's silence surrounding her father's death ${ }^{45}$ unable to understand her motives for this silence: 'Two years after the plane crash my mother performed an impossible feat: she made my father disappear. ${ }^{\prime}{ }^{4}$ The text mediates her anger towards her mother's erasing of her father's memory by showing that she loves her mother and seeks her guidance about her own uncertainty. Henderson uses direct representation of dialogue to convey this. She reproduces a phone conversation:

I don't know what I'm doing here. I feel like I'm wasting my life ... I have a crappy job, we live in this shitty apartment. My car's on its last leg. I don't know what to do. ${ }^{47}$

She asks her mother if she should leave. Her mother replies that she does not think that that would be the solution. She inquires if Henderson loves Miles. The dialogue is interspersed with reflection. The text depicts Henderson taking in her surroundings, described in detail: a shopping list with Miles' handwriting, pot holders by the stove and the calendar pinned to the wall. She reflects that 'all those bits of domesticity formed the working fabric of our relationship and I realized that this was how people build a life together, ..., in the day-to-day. The dish soap, the spoon rest, the coupons. ${ }^{48}$ Following this internal monologue the text returns to the conversation with her mother. She loves him more than anything is Henderson's unwavering reply. 'Then you stay' is the guidance she receives from her mother. ${ }^{49}$ This interplay between the detailed description of events and the text stepping back from the experience in order to contemplate it shows the function of memoir in mediating experience by reflecting upon and making sense of it from the vantage point of the present. Sven Birkerts argues that both the 'unprocessed feeling of the world' as it was experienced then 'and a reflective vantage point' that contemplates the experience and realises 
that these events 'made a different kind of sense over time' [author's emphasis] lies at the heart of memoir. ${ }^{50}$

Following the death of her husband, Henderson's post-loss grieving self is positioned as having lost love and happiness and in her state of grief, the self that wants to actualise her dreams is numbed.

Whereas Henderson's memoir narrates one dominant pair of adversarial selves, MacKellar's text is constituted around two dominant pairs of conflicting selves: firstly the working self that is in opposition to the voice of the grieving fatigued single mother and secondly the widowed self which is in conflict with the voice of the daughter who lost her mother to cancer.

The voice of the working self that likes her prestigious and stimulating job as history lecturer is positioned in the text in conflict with the grieving, overworked self that struggles to juggle single parenthood with her job and that yearns to retreat to the country for peace. The text represents MacKellar as being aware that her identity depends on the fulfilling and esteemed position she holds at university and fearing that she will become solely defined by her role as mother, thereby lacking an independent identity. As a result of this identity struggle MacKellar is crippled by her insecurities, asking herself stream of consciousness questions in relation to her selfhood:

Who am I if I am not an historian, a lecturer at university? ... Who am I if I don't have the reassurance of colleagues seeking my opinion on their work? Without the surety of my work, the blessed miracle of having a decent sum of money deposited in my bank account every week, will I become directionless, anonymous, invisible? ${ }^{51}$

MacKellar's concept of the self is shown to depend on her interactions with colleagues in her role as lecturer whose advice is sought by students and peers. This highlights the importance of external subject positions in the developmental process of narrative identity construction, whereby the self can only be understood in its dynamic interplay between internal and external voices and the negotiation they engage in. ${ }^{52}$

MacKellar's steadfast reluctance to surrender her tenured position creates a conflict with the realities of her everyday life as single mother:

Despite the fact I was not coping with juggling my job, my kids and my loss, I fought against the obviousness of my need to escape. For if I left, I was relinquishing a hard-won position at the university. Instead of ambition, I was now swamped with a longing for silence, for a place where I wasn't forced outside myself, a place ... where I didn't have to gather my courage in case I met someone who'd see the brilliant light emanating from my wounds. ${ }^{53}$ 
The experience of loss is mediated in the text through the different perspectives narrated from the position of the history lecturer and the position of single mother. These different viewpoints show that subject positions are like interacting characters in a story, whereby each position narrates its experiences from its own perspective, located in time and space. ${ }^{54}$

The voice of the single mother narrates the emotional strain of bringing her children to day care and school early in the morning: 'I carry bags - a day-care bag, school bag, library bag, handbag and my laptop, whose hard edges bang against my leg. ${ }^{55}$ Dropping off her young son at child care is heart-breaking: 'I have to prise his octopus fingers from around my heart and shut my ears to his screams. ${ }^{56}$ In drawing on the literary device of repetition by listing all the various bags and the metaphor of the octopus to show the clinginess and unhappiness of her son the subject position of overwhelmed single mother denotes strong physical and emotional strain.

The second set of dominant conflictual voices is based around two different types of losses MacKellar has experienced: the subject position of angry, betrayed and lost widow is narratively placed in a conflicting dialogical relationship with the voice of the daughter who lost her mother to cancer two years after her husband's suicide. The widowed self is unable to comprehend her husband's loss by suicide. This voice feels marked by her husband's death, because it perceives that he 'died with intent'. ${ }^{57}$ Smith and Watson suggest that every narrative voice has its own tone and emphasis, rhythm, syntax and affect. ${ }^{58}$ Here, the tone of the voice of the widow is distinctly evident in the level of disconnection and alienation that is expressed towards her most significant other, her 'closest companion of eleven years ${ }^{59}$ She cannot bear to name him in her memoir, referring to him throughout the narrative by the third person pronoun and the generic 'my husband'. The widowed self is plagued by unanswerable questions: 'I struggle with questions, trying to wrestle them into something meaningful... no matter how often I chase them away, these questions circle back and size up my strength' ${ }^{60}$ Some of her queries are expressed in the text as stream of consciousness questions: How dare he leave me? How dare he lie to me? ${ }^{61}$

The text, then, represents MacKellar as resisting the subject position of widow in her refusal to name her husband in the memoir and, equally, as being aware of her defiance: 'I fight every definition of widowhood his death throws at me.... He is the invisible adversary I shadow-box through the day. ${ }^{\prime}{ }^{2}$

Though MacKellar rejects the identity of widow, the voice of the widow who has survived her husband and seeks redemption is nevertheless present in the text. It believes that recovery depends on understanding her 
husband's suicide. The tone this voice employs is that of anger: 'if I resign, he'll have stolen my career as well as everything else'. ${ }^{63}$ She wants to hold him responsible for what he did both to herself and their young daughter. ${ }^{64}$ She feels a strong sense of betrayal, 'deceived, manipulated and treated as less than nothing ${ }^{65}$ because her husband did not inform her of an earlier episode of mental illness he experienced in his teens. At the same time, the complex subject position of widow that is constructed in the text is shown to embody not only anger and betrayal, but also feelings of missing him. She is aware of the way her husband defined her: her identity and sense of self and even her physical body: 'He lit me. Sent me high, beyond space, beyond time, he defined the edges of me'. ${ }^{66}$ And in relation to her material self she notes: "Slowly I'm reclaiming my body, for who knew that his absence would physically change the shape of me? It's so obvious to me that my body announces his departure to the world. ... But it's more primal than that—quite simply, my body is different without him. ${ }^{67}$

The fact that her husband was such a significant other to MacKellar that he even influenced her physical self shows the extent to which he had become meaningful to her and constitutive of her identity construction. The concept of the extended self is a fundamental assumption that underpins the theorising of the dialogical self. It positions the demarcation line between the self and the other as gradual rather than dualistic, suggesting a progressive transition between internal and external selves. ${ }^{68}$

The accusatory, angry voice wrestles with the voice of reason that logically lays out the realities of his mental illness. In one of these versions to explain his suicide, she paints him as the prince who wanted to protect his family from the ugliness of his illness. In another version she perceives him as a coward. And lastly, she thinks that maybe something was wrong with her for failing to save him. ${ }^{69}$ Her active searching for meaning shows MacKellar's strong emotional dependence on finding answers. This quest for meaning making is in accord with contemporary bereavement theory, which posits that finding meaning is key to the reconstruction of a new self following loss. ${ }^{70}$ Bereavement scholar and psychologist Robert Neimeyer suggests that if death cannot be accounted for meaningfully, survivors undergo 'the greatest discontinuity'. ${ }^{71}$ Discontinuity is evident in MacKellar's emotional need for answers in relation to her husband's suicide. The not knowing plagues her:

What I want is some precise definition, something scientific that can be measured telling me who my husband had become and where the man I married went. $^{72}$

The subject position of grieving daughter is qualitatively represented as the exact opposite of the widowed self. She holds nothing back in her 
grief, which feels 'pure and powerful' 73 and is 'open and raw and honest' ${ }^{7}{ }^{74}$ Whilst the purity of her grief for her mother is essential to MacKellar, there is no purity in her feelings for her husband. She bemoans that through his mental illness she lost her chance to mourn 'him sweetly and cleanly'. ${ }^{75}$ She views her husband's death as not by chance but by choice. What she sees as an act of choice 'robs' her of the ability to mourn him purely. ${ }^{76}$ Importantly, in contrast to her husband who had become for her someone she did not know, she feels that she knew her mother well.

Remembered others can continue to form subject positions in the dialogical self. Such a position can play a significant role in the dialogical self for extended periods of time with a stabilising effect. ${ }^{77}$ The text represents MacKellar as assigning a pivotal role to her mother, now the remembered other, who is an important player in inner conversation and who constitutes meaning for her:

She remains the measuring stick in my head, the magnetic north against which I line up my emotions. I worry about the shortcuts I take, at the morally ambiguous decisions over which I know she would confront me.... I worry about how much less of a person I am without her. ${ }^{78}$

The experience of loss is differentiated and mediated in the text, which shows that experience to vary with the specific type of loss that is portrayed. MacKellar is confronted by the fact that her two losses feel utterly different and ponders why this is so, why a death by suicide feels so unlike a death from cancer, why they are almost like a 'separate experience'.$^{79}$

The two distinctly different voices of loss are intertwined throughout the memoir and narratively placed in such close conflictual interdependent dialogical relationship that they have become inseparable: 'I can't find my way into one moment without being ambushed by another. ${ }^{80}$ The metaphor of ambush signifies the violent and uncertain nature of mourning a death by suicide. MacKellar's use of the language of violence-being ambushed, robbed-denotes her loss of agency, her perceived victimisation by her husband's 'choice' to die.

She realises that the entanglement of her two losses stops her from resolving her emotions. The anger towards her husband gets displaced by missing her mother. She feels that this enmeshing of the different emotions she has in relation to her husband and her mother stops them from being resolved which keeps them trapped within her. ${ }^{81}$

Memoir mediates lived experience, in this case two different types of losses, by drawing on reflection. This is evident in the juxtaposing of vivid descriptions of MacKellar's emotions that employ the language of war with inner monologue that depicts her state of confusion. 
The wind has got under my mind. It works away at my head and buzzes around until it finds something to prise loose. My thoughts flap like a piece of corrugated iron on the roof. Not rhythmically but violently. ... I wonder how one death can cause me to lose faith and another death seems only to confirm that there has to be some sort of natural order to life, some allcontrolling being, some God. ${ }^{82}$

The self that is marked by two losses yearns to mourn her mother separately from her husband, to shield its purity, but the widowed voice is incapable of keeping these conflicting grieving selves apart, thereby polluting the perceived pureness of the death by cancer.

Moments of loss merge into each other until they form a tangled mess. I try to tease them apart so each may be dealt with individually... But they loop and curl around each other so that one begins before the other ends. ${ }^{83}$

In addition, these two selves interact differently with the outside world. The voice of the grieving daughter is met with sympathy, kindness and understanding. Other people instinctively 'know [cancer] and in their knowing you are not so alone' ${ }^{84}$ By contrast, the widowed self is denied the comfort of empathy and closeness; instead it is met with a wall of cold disbelief. MacKellar perceives loss by suicide as savage, and 'no one knows how to approach it. Not even me' ${ }^{85}$ These strikingly different reactions by others to the two losses portrayed in the text show that not only internal and internalised voices are part of the extended, multivoiced self, but also interactions with actual others. Other people's responses to MacKellar's two losses are represented as mediating her experience of loss, thus contributing to her perception that the two losses are unlike each other. ${ }^{86}$ This highlights the close interconnection between internal and external positions and shows that both internal dialogue and represented external dialogue with others are involved in the process of narrative identity construction. ${ }^{87}$

\section{THE PROCESS OF NARRATIVELY RECONCILING ADVERSARIAL SELVES}

Having shown the dominant adversarial selves expressed in the memoirs, I will now examine the process of repositioning and negotiation of these selves that takes place in the text.

The dynamic nature of the dialogical interchange is evident in Henderson's memoir. After her husband's death, she receives a love letter 
from him that he had written to her in case of his death, which functions as the impulse for reconstruction. It ends:

Live your life on earth to the max. You have so many options with what to do with your life. Pursue your dreams wisely, with all your heart, with honour and with decency. I will love you forever, look on you always, and see you soon. I love you. ${ }^{88}$

Inspired by Miles' encouragement, Henderson's post-loss self dares to go after her dream of becoming a writer. Miles's internalised position of loving husband whose occupation denied her self-actualisation, framed as distressing, is now repositioned and constructed as positive, mediating her self-doubt. The new voice of self-actualisation reflects:

[who would have thought] that Miles would be the catalyst for this blossoming life, that my time with him would lay the foundation for some braver, more fearless me. That through knowing him and loving him, I would become someone with the wherewithal to seize my dreams.

As such, the formerly adversarial selves are repositioned into a reconciliatory relationship in the post-loss context of Miles' letter urging Henderson to realise her dreams. This shows an internalisation of her external significant other beyond his death in accord with the 'other-in-the-self' concept where Miles plays a pivotal role in inner conversation and is constitutive of meaning making in the text.

The reconstruction of Henderson's identity that takes place in the text shows that a subject position is not fixed but dependent on the context, which can include the voice of a significant other, in this case a deceased other who is represented in the text not as a remembered other but as an actual voiced position in the form of a letter. Whereas previously her husband's voice was constructed as a hindrance to actualisation it is now re-constructed as a catalyst for making her dreams come true.

Subject positions are not stable centres of knowledge then, but perspectives that are constructed depending on the context. They are neither inherently good nor bad, but are narratively constructed as such in particular situations and this construction can change if the context is altered. As such, the dialogical self exists in both time and space through the process of positioning. ${ }^{89}$

Positioning and repositioning in autobiographical writing allows the dialogical self to mediate the experience of loss in response to altered perspectives and to build narrative coherence. Unity is conceptualised as the result of a dynamic process of narrative dialogical interchange that 
allows for the possibility of new perspectives and insights to emerge in the text, including the capacity to reconstruct subject positions. ${ }^{90}$

Similarly, MacKellar's adversarial selves of successful academic and seeking peace in the country are reconciled in the text. The voice that seeks peace repositions life in the country as meaningful and not exclusive of her intellectual pursuits. Whilst living in the country, MacKellar is offered a job of writing a historical book, which her intellectual voice relishes, thus recognising that scholarly satisfaction is possible outside the context of her job as university lecturer, though more challenging in the absence of a library and readily available colleagues. ${ }^{91}$ The intellectual fulfilment and enjoyment of financial rewards experienced by this subject position as a result of writing this book provides a new context, thereby allowing both selves to co-exist in a reconciliatory relationship.

MacKellar's self that is deeply troubled by not understanding her husband's suicide, thereby preventing her from finding peace, seeks solace in a variety of texts, including Janet Frame and in particular classical texts such as Euripides' Heracles. ${ }^{92}$ She is drawn to the art form of tragedy. ${ }^{93}$ The insights gained from these books and their leading protagonists can be seen as new positions being introduced to an existing position, which leads to a reorganisation of the self. One of the most influential texts for MacKellar is that by the ancient Greek poet Sappho. Inspiring figures in literature such as Sappho can serve as a catalyst for helping to create order in confused or oppositional subject positions. ${ }^{94}$ The widowed voice reaches a conclusion upon reflecting on the art form of tragedy: that no matter how deep she dives under the sea she will never really understand why her husband committed suicide. This is a step towards integration of the inconsolable self that feels inner peace is out of reach unless she understands and the subject position of recovery. This voice is further repositioned by being placed in juxtaposition with a memory from the past early on in her marriage, namely a trip to Alaska, a pivotal time in her life which she repeatedly recalls throughout the entire narrative. 'Though I am afraid of the ocean, I have to accept its overwhelming presence if I am to sleep' ${ }^{95}$ The positioning of this scene in the text denotes a change in attitude of the self that desperately needed understanding: it recognises that sometimes in life you have to accept something for what it is. In accord with Sappho's words, this self finds herself wanting again, life and love. ${ }^{96}$ I suggest that the voice of loss is integrated rather than reconciled through the process of negotiation in the text. The voice of the widow who cannot move forward without understanding her husband's suicide would prefer to comprehend his actions, but has accepted that this is out of her reach and no longer makes recovery dependent on gaining such knowledge. 
As far as the grieving daughter subject position is concerned, connection to place allows the rebuilding of continuity. MacKellar has moved with her young children to the farm where her mother grew up, thereby creating the ongoing connection to her mother she craves for herself and her children:

It's a rare sort of continuity: my children walk along the same track she used: they catch the bus along the same road on which she rode her pony to school; they sit in the same space she sat in to learn to read and write. It feels safe to be part of this continuity. ${ }^{97}$

Her children are engrossed in the stories she repeats that her mother used to tell her as a child. MacKellar is able to establish 'continuing bonds', a concept that is a central component of contemporary grief theory, ${ }^{98}$ with her mother without negative interference from the voice of the widow in the text by writing about her and reflecting upon her mother's continuing role in her life.

Furthermore, the new life in the country represents a catalyst for reflection and mediates the experience of grief. It inhabits a central role in MacKellar's writing. In the latter part of the memoir, MacKellar repeatedly describes vignettes of farm life, narrating in depth the soothing and grounding nature of farm life:

Digging locates me. I stop struggling for words and concentrate on the ground. I push my spade into the soil and turn over the manure. The physical effort soothes. ${ }^{99}$

The act of observing nature plays an influential role in MacKellar's repositioning: "the burdens of living seem to shrink in front of the beauty of a rearing horse'. ${ }^{100}$ She frames the concept of beauty as the catalyst for transformation, reflecting that she expected to retreat and hide in the country, to inhabit hopelessness, but instead found beauty, adding that 'existence depends on beauty'. ${ }^{101}$

As she watches her daughter horse riding she recognises that she is happy. Whilst lying on the ground and enjoying the feel of the earth she realises that 'this place is tattooed into me'. ${ }^{102}$ The connection to her mother's childhood home and being grounded in nature allows MacKellar to integrate the loss of her mother and to find inner peace.

Furthermore, in accord with the multi-voiced nature of the dialogical self there is another voice that is comforted by life in the country. Witnessing the joy her children experience horse riding and interacting with animals forges an integrative connection with her husband. MacKellar 
narrates a pivotal conversation she had with her husband before they had children whilst observing another family in a roadhouse who had just come from a horse competition weekend: her husband was 'transfixed' by how much these country children radiated and expressed how much he would want to give their own children the kind of upbringing they had just witnessed. ${ }^{103}$ MacKellar comes to realise that she is giving their children what their father wanted for them.

\section{CONCLUSION}

The analysis of the two grief memoirs under review examined the authors' dialogical selves with the intention of exploring autobiographical subjectivity that mediates the particular experience of young widowhood. I have focused my analytical lens in this paper specifically on the dialogical relationship and interaction between the memoirists' pivotal pre- and postloss selves.

The memoirs express the fragmentation of selfhood evoked by young widowhood. The textual analysis showed Henderson's and MacKellar's repositioning of their pre- and post-loss selves into a reconciliatory or integrative relationship following a prolonged and complex process of dialogue that also incorporated multiple other voices, thus demonstrating how the dialogical self undergoes a dynamic developmental process in the text that depends on the representation and repositioning of pre- and post-loss voices. The analysis has illustrated that narrative coherence and a unified sense of self can be constructed in autobiographical writing out of the experience of loss even in the face of conflicting voices that bear the signature of the most intense emotions. The texts then highlight the role autobiographical writing is capable of playing in contributing to the re-building of narrative identity and in mediating the experience of spousal loss at a young age. As such, the young widow memoir can make an important contribution to identity theory.

\section{WORKS CITED}

Ashley, K. M., L. Gilmore, and G. Peters. Autobiography E Postmodernism. Amherst: University of Massachusetts Press, 1994.

Ball, J. F. "Widow's Grief: The Impact of Age and Mode of Death." Omage 7 (1977): 307-333. Birkerts, S. The Art of Time in Memoir: Then. Again. St. Paul: Graywolf, 2008.

Eakin, P. J. "Autobiography as Cosmogram." StoryWorlds: A Journal of Narrative Studies 6.1 (2014): 35 .

Eakin, P. J. "Self and Self-Representation Online and Off." FRAME, Journal of Literary Studies 28.1 (2015): 16. 
Haase, T. J. and N. Johnston. "Making Meaning out of Loss: A Story and Study of Young Widowhood." Journal of Creativity in Mental Health 7.3 (2012): 204-221.

Henderson, A. Unremarried Widow: A Memoir. New York: Simon and Schuster, 2014.

Hermans, H. J. "The Construction of a Personal Position Repertoire: Method and Practice." Culture Eै Psychology 7.3 (2001): 323-366.

Hermans, H. J. "How to Perform Research on the Basis of Dialogical Self Theory?" Introduction to the special issue." Journal of constructivist Psychology 21.3 (2008): 185-199.

Hermans, H. J. and T. Gieser. "History, Main Tenets and Core Concepts of Dialogical Self Theory." In H. J. Hermans and T. Gieser, eds. Handbook of Dialogical Self Theory. New York: Cambridge University Press, 2011. 1-22.

Hunt, C. and F. Sampson. Writing: Self and Reflexivity. Basingstoke: Palgrave Macmillan, 2006.

Levinson, D. S. "Young Widowhood: A Life Change Journey." Journal of Personal E Interpersonal Loss 2.3 (1997): 277-291.

MacKellar, M. When it Rains. Milsons Point: Random House Australia, 2010.

MacKellar, M. How to Get There. Milsons Point: Random House Australia, 2014.

McAdams, D. P. "The Case for Unity in the (post) Modern Self." Self and Identity: Fundamental issues. New York: Oxford University Press, 1997. 46-78.

McAdams, D. P., R. E. Josselson, and A. E. Lieblich. Eds. Identity and Story: Creating Self In Narrative. Washington, DC: American Psychological Association, 2006.

Mullan, J., M. Skaff, and L. Pearlin. "The Bereavement Process: Loss, Grief and Resolution" In I. B. Corless, B. B. Germino, and M. Pittman, Eds. Dying, Death, and Bereavement: A Challenge for Living. New York: Springer Publishing Company, 2006.

Neimeyer, R. Ed. Meaning, Reconstruction and the Experience of Loss. Washington, DC: American Psychological Association, 2001.

Neimeyer, R. "Widowhood, Grief, and the Quest for Meaning." In D. Carr, R. Nesse, and C. Wortman, Eds. Spousal Bereavement in Late Life. New York: Springer Publishing Company, 2006. 227-252.

Neimeyer, R. "Reconstructing the Self in the Wake of Loss: A Dialogical Contribution." In H. J. Hermans and T. Gieser, Eds. Handbook of Dialogical Self Theory. New York: Cambridge University Press, 2011.

Raggatt, P. T. "Positioning in the Dialgocial Self: Recent Advances in Theory Construction." In H. J. Hermans and T. Gieser, Eds. Handbook of Dialogical Self Theory. New York: Cambridge University Press, 2011.

Smith, S. and J. Watson. Reading Autobiography: A Guide for Interpreting Life Narratives. 2nd ed. Minneapolis: University of Minnesota Press, 2010.

Stanley, L. The Auto/Biographical I: The Theory and Practice of Feminist Auto/biography. Manchester: Manchester University Press, 1992.

Van Den Hoonaard, D. K. "Identity Foreclosure: Women's Experiences of Widowhood as Expressed in Autobiographical Accounts." Ageing and Society 17.05 (1997): 533-551.

Weedon, C. Feminist Practice and Poststructuralist Theory. London: Basil Blackwell, 1987.

\section{ABOUT THE AUTHOR}

Katrin Den Elzen is a PhD candidate in Creative Writing at Curtin University in the department of Media, Culture and Creative Arts. This doctorate entails a creative component and an accompanying thesis. The main focus of her work is the young widow memoir, specifically, how memoirists rebuild the fragmented self in the text. She 
is writing a grief memoir about the illness and loss of her husband and the rebuilding of her life and identity. Her academic articles have appeared in TEXT and Life Writing and her creative work has been anthologised in Europe.

\section{NOTES}

1 Henderson, A. (2014). Unremarried Widow: A Memoir, Simon and Schuster.

MacKellar, M. (2010). When it Rains, Random House Australia.

2 Hermans, H. J. and T. Gieser (2011). "History, main tenets and core concepts of dialogical self theory" in Handbook of dialogical self theory, Hermans, H. J. and Gieser, T. (Eds.), Cambridge University Press, 1-22.

3 Eakin, P. J. (2014). Autobiography as Cosmogram. StoryWorlds: A Journal of Narrative Studies, 6(1), 35, Hermans, H. J. (2008). "How to perform research on the basis of dialogical self theory?" Introduction to the special issue. Journal of constructivist Psychology, 21(3), 189, McAdams, D. P. (1997). "The case for unity in the (post) modern self." Self and identity: Fundamental issues, Oxford University Press, 46-78.

4 MacKellar, M. (2014). How to get there. Random House Australia.

5 http://artishenderson.com.

6 According to the US Census Bureau, 2010, young widowhood is rare, ranging from $0.1 \%$ of all women in the age cohort at 20-24 years of age to $1.6 \%$ at $40-44$ years of age. This is in contrast to older widowhood, which has become a common life event, whereby over half of the married women aged 65 and older are widowed (Table 57: Marital Status of the population by Sex and Age).

7 Haase, T. J. and N. Johnston (2012). "Making Meaning out of Loss: A Story and Study of Young Widowhood." Journal of Creativity in Mental Health 7(3): 204-221; Levinson, D. S. (1997). Young widowhood: A life change journey. Journal of Personal E Interpersonal Loss, 2(3), 277-291; Van Den Hoonaard, D. K. (1997). Identity foreclosure: Women's experiences of widowhood as expressed in autobiographical accounts. Ageing and Society, $17(05), 533-551$.

8 Ball, J. F. (1977). "Widow's grief: the impact of age and mode of death." Omage, 7, 307-333.

9 Haase, T. J. and N. Johnston (2012). "Making Meaning out of Loss: A Story and Study of Young Widowhood.”; Levinson, D. S. (1997). "Young widowhood: A life change journey."

10 Smith, S., \& Watson, J. (2010). Reading autobiography: A guide for interpreting life narratives (2nd edition). University of Minnesota Press, 35.

11 Ibid, 34.

12 Hunt, C., \& Sampson, F. (2006). Writing: Self and reflexivity. Palgrave Macmillan, 9-12.

13 Stanley, L. (1992). The auto/biographical I: The theory and practice of feminist auto/biography. Manchester University Press, 14; Weedon, C. (1987). Feminist practice and poststructuralist theory, London: Basil Blackwell, 21.

14 Hunt, C., \& Sampson, F. (2006). Writing: Self and reflexivity, 12.

15 Eakin, P. J. (1988). "Narrative and Chronology as Structures of Reference and the New Model Autobiographer." Studies in Autobiography. Olney, J (Ed.). New York: Oxford UP, 38, quoted in Ashley, K. M., Gilmore, L., \& Peters, G. (1994). Autobiography Ẽ postmodernism. University of Massachusetts Press, 212.

16 Eakin, P. J. (2015). "Self and Self-Representation Online and Off." FRAME, Journal of Literary Studies 28.1, 16.

17 Hermans and Gieser. "History, main tenets and core concepts of dialogical self theory", 2.

18 Ibid, 3. 
19 Hermans, "How to perform research on the basis of dialogical self theory?", 188.

20 McAdams, "The Case for Unity in the (Post)Modern Self", 70.

21 McAdams, D. P., Josselson, R. E., \& Lieblich, A. E. (Eds.) (2006). Identity and story: Creating self in narrative, American Psychological Association, Washington DC, 5.

22 Eakin, "Autobiography as Cosmogram", 35.

23 Smith and Watson, Reading autobiography, Hermans, H. J. (2008). "How to perform research on the basis of dialogical self theory?"

24 Hermans, "How to perform research on the basis of dialogical self theory?", 189.

25 MacKellar, When it Rains, 60.

26 Henderson, Unremarried Widow, $156+157$.

27 Ibid, 158.

28 Smith, S., \& Watson, J. (2010). Reading autobiography: A guide for interpreting life narratives, 37. 29 MacKellar, When it Rains, 31.

30 Mullan, J., Skaff, M \& Pearlin, L. (2006). "The Bereavement Process: Loss, Grief and Resolution" in Corless, I. B., Germino, B. B. \& Pittman, M. (Eds.), Dying, death, and bereavement: A challenge for living. New York: Springer Publishing Company, 232.

31 Ibid, 68.

32 Ibid, 31.

33 Henderson,Unremarried Widow, 68.

34 Ibid, 10.

35 Ibid.

36 Ibid, 47.

37 Ibid, 10.

38 Hermans, "The construction of a personal position repertoire: Method and practice.", Culture E Psychology, 7(3), 341.

39 Henderson, Unremarried Widow, 44.

40 Ibid.

41 Ibid, $72+73$.

42 Ibid, 188.

43 Hermans, "How to perform research on the basis of dialogical self theory?, 186.

44 Ibid, 186.

45 Henderson, Unremarried Widow, 172.

46 Ibid, 71.

47 Ibid.

48 Ibid, 72.

49 Ibid.

50 Birkerts, S. (2008). The Art of Time in Memoir: Then. Again. St. Paul: Graywolf, 23.

51 MacKellar, When it Rains, $78+79$.

52 Hermans, "How to perform research on the basis of dialogical self theory?", 187.

53 MacKellar, When it Rains, 39.

54 Hermans and Gieser. "History, main tenets and core concepts of dialogical self theory", 17.

55 MacKellar, When it Rains, 38.

56 Ibid, 39.

57 Ibid, 5.

58 Smith and Watson, Reading Autobiography, 79.

59 MacKellar, When it Rains, 5.

60 Ibid, 50.

61 Ibid, 46.

62 MacKellar, When it Rains, 149.

63 Ibid, 78. 
64 Ibid, 135.

65 Ibid, 4.

66 Ibid, $45+46$.

67 Ibid, $67+68$.

68 Ibid, 188.

69 MacKellar, When it Rains, 51.

70 Neimeyer, R. (Ed.). (2001). Meaning, Reconstruction and the Experience of Loss. Washington DC: American Psychological Association, xii+4.

71 Neimeyer, R. (2006)."Widowhood, Grief, and the Quest for Meaning” in Carr, D., Nesse, R. and Wortman, C. (Eds.), Spousal bereavement in late life. New York: Springer Publishing Company, 227-252, 236.

72 MacKellar, When it Rains, 124.

73 Ibid.

74 Ibid, 98.

75 Ibid, 136.

76 Ibid, 100.

77 Hermans and Gieser, "History, main tenets and core concepts of dialogical self theory", 17.

78 MacKellar, When it Rains, 98.

79 Ibid.

80 Ibid, 99.

81 Ibid.

82 Ibid.

83 Ibid, 97.

84 Ibid, 4.

85 Ibid.

86 Hermans and Gieser, "History, main tenets and core concepts of dialogical self theory", 9 .

87 Ibid, 18.

88 Henderson, Unremarried Widow, 135.

89 Raggatt, P. T. (2011). "Positioning in the dialgocial self: recent advances in theory construction." In H. J. Hermans \& T. Gieser (Eds.), Handbook of Dialogical Self Theory: Cambridge University Press, 29.

90 Hermans, "How to perform research on the basis of dialogical self theory?", 192-194.

91 MacKellar, When it Rains, 55, $79+119$.

92 Ibid, 30, 128.

93 Ibid, 30.

94 Hermans and Gieser, "History, main tenets and core concepts of dialogical self theory", 17.

95 MacKellar, When it Rains, 218.

96 Ibid, 145.

97 Ibid, 116.

98 Neimeyer, R. (2011). Reconstructing the self in the wake of loss: a dialogical contribution. In H. J. Hermans\& T. Gieser (Eds.), Handbook of Dialogical Self Theory: Cambridge University Press, 375.

99 Ibid, 158.

100 Ibid, 164.

101 Ibid, 154.

102 Ibid, $185+186$.

103 MacKellar, When it Rains, 212. 